\title{
Training on intravenous medication administration in pediatric nursing: a before-after study
}

\author{
Treinamento sobre administração de medicamentos endovenosos na enfermagem pediátrica: \\ estudo antes e depois \\ Formación en administración de fármacos intravenosos en enfermería pediátrica: \\ un estudio antes-después
}

\section{How to cite this article:}

Custódio IL, Lima FET, Pascoal LM, Barbosa LP, Carvalho REFL, Almeida PC, Pinheiro PNC, Barbosa IV, Ribeiro SB. Training on intravenous medication administration in pediatric nursing: a before-after study. Rev Esc Enferm USP. 2021;55:e20210195. DOI: https://doi.org/10.1590/1980-220X-REEUSP-2021-0195

\author{
Ires Lopes Custódio ${ }^{1}$ \\ Francisca Elisângela Teixeira Lima ${ }^{1}$ \\ Lívia Maia Pascoal² \\ (D) Lorena Pinheiro Barbosa ${ }^{1}$ \\ D Rhanna Emanuela Fontenele Lima de \\ Carvalho $^{3}$

\section{(iD) Paulo César Almeida ${ }^{3}$ \\ D Patrícia Neyva da Costa Pinheiro ${ }^{1}$ \\ (D) Islene Victor Barbosa ${ }^{4}$ \\ (D) Silvania Braga Ribeiro ${ }^{5}$} \\ ${ }^{1}$ Universidade Federal do Ceará, Fortaleza, CE, \\ Brazil. \\ ${ }^{2}$ Universidade Federal do Maranhão, Imperatriz, \\ MA, Brazil. \\ ${ }^{3}$ Universidade Estadual do Ceará, Fortaleza, CE, \\ Brazil. \\ ${ }^{4}$ Universidade de Fortaleza, Fortaleza, CE, Brazil. \\ ${ }^{5}$ Hospital Dr. Carlos Alberto Studart Gomes, \\ Fortaleza, CE, Brazil.
}

\begin{abstract}
Objective: To evaluate the effect of training on intravenous medication administration in pediatric patients on nursing staff's learning and response. Method: This is a quasi-experimental study (pre- and post-test), with 38 nursing professionals who participated in training on administration of intravenous (IV) medication in pediatric patients with heart disease. For data collection, a questionnaire with 19 items was applied to evaluate participants' learning before (pre-test) and after (post-test) training. Data were analyzed by descriptive and analytical statistics (binomial and Friedman tests). Results: Nurses predominated (52.6\%), mean age 41.2 years and 9.8 years of professional experience in pediatrics. For learning evaluation, there was an increase in the rate of hits from the pre-test to the posttest in 13 items, with a significant difference $(p<0.05)$ in the items: removing adornments to sanitize hands; wearing gloves when administering medication; administering medication with gloves, mask and goggles; and checking patient name by asking their companion. Conclusion: Training had positive effects on nursing professionals' learning and reaction.
\end{abstract}

\section{DESCRIPTORS}

Patient Safety; Infusions, Intravenous; Medication Errors; Pediatric Nursing; Inservice Training. 


\section{INTRODUCTION}

The medication administration system in pediatric patients is complex, as children have their own characteristics that contribute to incident occurrence at any stage of the medication system (prescription, dispensing and administration); and managers and health teams must promote an organizational culture that allows for restructuring processes and implementing patient safety strategies ${ }^{(1)}$.

When addressing safe environment in healthcare services, the possibility of incidents in hospital care should be considered, especially in medication preparation and administration. This process involves the nursing team, being one of their greatest responsibilities, as it corresponds to one of the last barriers capable of intercepting and preventing incidents with medications with or without damage (adverse events) $)^{(1-2)}$.

The most common incidents in medication administration in pediatric hospitals are related to the intravenous route $(\mathrm{IV})^{(2)}$. Errors in hospitals during IV medication preparation and administration in the pediatric population were reported at a rate of 13 to $84 \%$,indicating the need for corrective actions and implementation of control measures to reduce the risk of errors ${ }^{(3)}$. Several factors are mentioned, such as: lack of pharmaceutical forms available in dosages and concentrations suitable for children; need to calculate individual doses according to age, weight, body surface area; clinical condition; and occurrence of accidental poisoning. The adaptations made to enable medication use in children involve significant risks and deviations in the final dose ${ }^{(4)}$.

Due to the importance of medication system safety to prevent unintended harm as a result of errors, the World Health Organization (WHO) has launched the third Global Patient Safety Challenge, with the topic Medication without Harm, which aims to globally reduce preventable serious medication-related harm by $50 \%$, and addresses four domains in medication safety, namely: involve patients and the public; medicines as products; education, training and monitoring of professional healthcare; and medication management systems and practices. For this reason, institutions should promote continuing education programs, including training on prescription, distribution, preparation, labeling, administration and monitoring of medicines in pediatrics and encourage professionals to seek knowledge, adhering to an incident prevention policy ${ }^{(5)}$.

The safety protocol in the prescription, use and administration of medication ${ }^{(6)}$ recommends that, in order to ensure safety in this process, the focus should be on a systemic view, supported by technical-scientific knowledge, to ensure quality of care. These contents are essential for incident prevention. In this context, training on preparation and administration of medications aimed at the nursing team can contribute to patient safety, enabling professionals to practice safe, above all, through the identification of weaknesses and improvements to be implemented ${ }^{(6)}$. However, to verify the effect of training, four types of evaluation are indicated: reaction, learning, behavior and results ${ }^{(7)}$.
Given the above, the objective was to evaluate the effect of training on IV medication administration in pediatric patients on the nursing team's learning and reaction. The study hypothesis was: training on IV medication administration has a positive effect on the pediatric nursing team's learning and reaction.

\section{METHOD}

\section{Design of Study}

This is a quasi-experimental study with pre- and post-test, in a single group, which participated in training on administration of IV medications in pediatric patients with heart disease.

\section{LOCAL}

The study was carried out in a public hospital in Fortaleza, Ceará, Brazil, in three pediatric cardiology units with 37 beds, 20 in a Pediatric Inpatient Unit, nine in a Preoperative Pediatric Intensive Care Unit and eight in a Postoperative Pediatric Intensive Care Unit. Every month, an average of 100 children and adolescents with cardiac diseases are hospitalized. Higher education professionals with a workload of 20 or 30 hours and mid-level professionals with 20 or 40 hours a week, on day and night shifts for 12-hour shifts work in these units, distributed according to each professional's workload. The nursing staff assistance in the process of administering IV medications to pediatric patients with heart disease involves: reading the medical prescription; nurses' schedule, signature and stamp, double checking of potentially dangerous medications; organization, selection, preparation of material and administration of IV medication; dispensing of materials used and checking IV medication administration in the prescription.

The institution in which the research was carried out maintains a permanent education nurse in the pediatric sectors who develops training in professional admission in pediatric units, clinical sessions and in the workplace (monthly), due to professionals' difficulty to be absent from the sectors, addressing various themes identified during their work or by professionals' demands.

\section{Population}

The population consisted of 120 professionals from the nursing staff working in care practice, administering IV medications to pediatric patients with heart disease in those units.

\section{Sample Definition}

The sample, selected for convenience, was composed of 38 professionals, 20 nurses and 18 nursing technicians who work in the administration of IV medications in the pediatric cardiology unit for at least six months and carry out the training. Professionals on vacation, leave or away from their activities were excluded. Not having participated in all stages of training constituted a discontinuity criterion. Thus, 82 professionals were excluded, of which 43 did not agree to 
participate in the study, 15 were on vacation, 13 on sick leave and 11 discontinued; of these, 10 did not complete learning evaluation (pre-test) and one did not participate in the last phase of the training.

The absence of sample calculation is justified, as the entire population of 120 professionals was invited to participate in the study. However, only 38 of them could be absent from work for their participation, considering this aspect as a limitation of the methodological quality of the study.

\section{Data Collection}

Data collection was carried out from June 2018 to January 2019. Professionals underwent training on IV medication administration in pediatric patients with heart disease. Six nurse instructors with experience in child health, patient safety and medication administration in pediatrics participated in the training, who were responsible for data collection. The training implementation was carried out in three phases with different colors (Figure 1): Phase 1: blue; Phase 2: green; Phase 3: purple (moment immediately after training) and pink (evaluation after six months). The evaluations were carried out before and after training and evaluation levels are linked by black arrows.

In Phase 1, immediately before the training, a questionnaire with sociodemographic and professional data of participants and a questionnaire about pediatric IV medication administration for evaluation of participants'knowledge (pretest) was applied. Questionnaires were answered individually at the locations where the nursing staff was trained. The training lasted approximately 180 minutes.

The questionnaire on medication administration was constructed by researchers and validated by experts, based on guidelines for creating an effective learning evaluation form $^{(7)}$ and in the protocol for prescription, use and administration of medications ${ }^{(6)}$, with 19 actions distributed in six domains: 1) medical prescription reading; 2) hand hygiene; 3 ) environment organization and material selection (preparation of adequate material); 4) IV medication preparation; 5) guidance about the procedure for children and/or companion; and 6) technique for administering IV medications and monitoring patients' reactions to them. In each pre-test action, participants should tick true or false.

In Phase 2, training was implemented in the workplace, in a reserved room, individually or collectively, according to participants' feasibility. There was no stratification in the training between professional categories of nurses and nursing technicians, and the Phase 1 protocol contents ${ }^{(6)}$ were addressed. The training met the 10 steps proposed by Kirkpatrick and Kirkpatrick ${ }^{(7)}$. In addition to explaining nurses' activities in the six domains of the protocol ${ }^{(6)}$, the exclusive practices of nurses were also reinforced, such as monitoring of nursing technicians, timing of prescriptions with signature and use of stamp, attention to medications that need double checking, such as potentially dangerous medicines (PDM) and, finally, monitoring of patients' reactions. The activities aimed at nursing technicians were also related to the six domains of the protocol ${ }^{(6)}$.

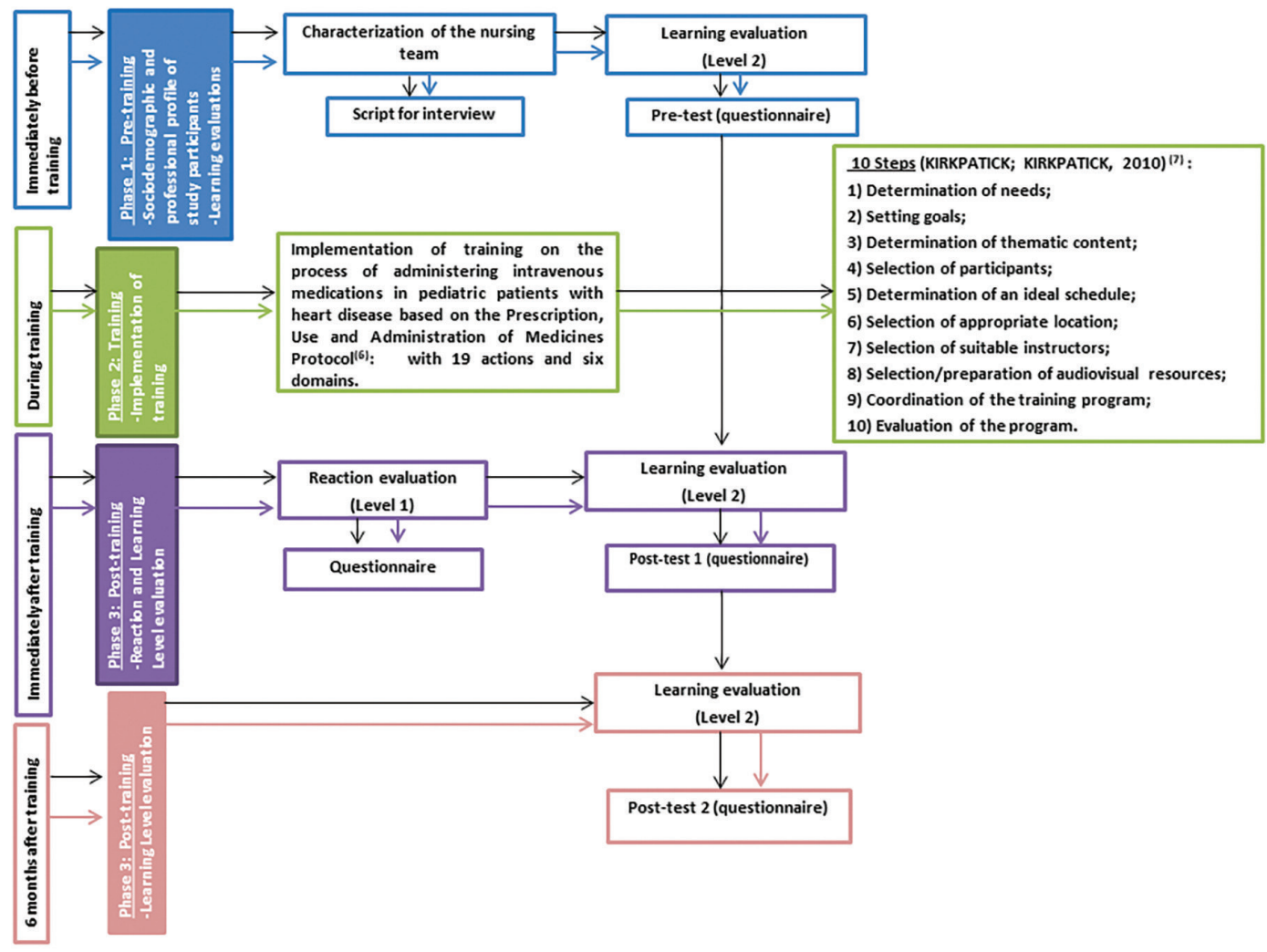

Figure 1 - Flowchart of the training conducted - Fortaleza, CE, Brazil, 2018-2019. 
It was necessary to carry out the training 28 times to contemplate professionals who met the inclusion criteria individually (23 meetings) and collectively (five times with groups of three people). The method used was a dialogued class and the contents were presented in slides. When possible, the adopted technological resource (a protocol) ${ }^{(6)}$ was read by the instructors, accompanied by the training participants, with interpretation and reading of the resource delivered, maintaining the debates and clarifying doubts.

In Phase 3, immediately after the end of the training, reaction and learning evaluations were performed (post-test 1). Six months after training (post-test 2), learning was evaluated again, aiming at fostering a culture of permanent evaluation, in addition to checking the existence of positive effects of the training ${ }^{(7)}$.

To evaluate the nursing team's reaction in relation to training, a questionnaire designed according to literature recommendations was applied ${ }^{(7)}$. It contained 12 items (Table 2), organized on a Likert scale, with answers 1 (poor), 2 (fair) and 3 (good) being considered inadequate, and answers 4 (very good) and 5 (excellent) as adequate.

\section{Data Analysis and Treatment}

Data were processed in SPSS 20.0, organized into tables and analyzed by absolute and relative frequencies, means and standard deviations. The binomial test and the Friedman test were used with a confidence level of 5\%, and items that presented a correct rate $>80 \%$ were considered adequate ${ }^{(8)}$.

\section{Ethical AspeCts}

The study was approved by the Institutional Review Board of a hospital (Hospital Dr. Carlos Alberto Studart Gomes), under Opinion 2,217,474, in 2017. All ethical aspects related to research with human beings were respected, in accordance with Resolution 510/2016 of the Brazilian National Health Council (Conselho Nacional de Saúde).

\section{RESULTS}

In this study, there was a predominance of women $(100 \%)$, nurses $(52.6 \%)$, with a mean age of $41.2( \pm 11.8)$ years, professionals with a graduate degree $(52.6 \%)$ and average training time of $13.1( \pm 8.3)$ years. The average time of experience with pediatric patients was $9.8( \pm 6.4)$ years and with IV medication was $11.6( \pm 7.1)$ years. The monthly workload ranged from 86 to 360 hours, with an average of $168.8( \pm 57.8)$ hours. The professionals worked mainly in the morning and afternoon shifts (day shift) (52.6\%).

The learning evaluation in the three moments (before, immediately after training and six months after) is described in Table 1.

It was found that there was an increase in the number of hits between the pre- and post-test immediately and after

Table 1 - Distribution of hits by nursing professionals according to actions evaluated before and after training - Fortaleza, CE, Brazil, 2018-2019.

\begin{tabular}{|c|c|c|c|c|}
\hline Actions in medication administration & $\begin{array}{l}\text { Pre-test } \\
\text { N }(\%)\end{array}$ & $\begin{array}{l}\text { Post-test } 1^{+} \\
\mathrm{N}(\%)\end{array}$ & $\begin{array}{l}\text { Post-test } 2^{\ddagger} \\
\quad \mathrm{N}(\%)\end{array}$ & $\mathbf{p}^{\S}$ \\
\hline 1. Understanding medical prescription & $37(97.4)$ & $38(100)$ & $38(100)$ & 0.368 \\
\hline 2. Checking patient name with prescription & $37(97.4)$ & $38(100)$ & $38(100)$ & 0.368 \\
\hline 3. Understanding medical prescriptions prevent patient harm & $36(94.7)$ & $36(94.7)$ & $35(92.1)$ & 0.846 \\
\hline 4. Sanitize hands before and after administering medication & $35(92.1)$ & $37(97.4)$ & $38(100)$ & 0.174 \\
\hline 5. Removing adornments is necessary for hand hygiene & $25(65.8)$ & $27(71.1)$ & $34(89.5)$ & 0.029 \\
\hline 6. Sanitizing the hands by rubbing the thumbs in a circular motion using the opposite palm & $35(92.1)$ & $38(100)$ & $37(97.4)$ & 0.174 \\
\hline 7. When administering IV medication, it is mandatory to wear glove & $23(60.5)$ & $35(92.1)$ & $38(100)$ & 0.022 \\
\hline 8. When administering IV medication, it is mandatory to wear gloves, mask and goggles & $27(71.1)$ & $32(84.2)$ & $36(94.7)$ & 0.009 \\
\hline 9. Cleaning, organizing the bench and selecting the right material is a safe action & $33(86.8)$ & $37(97.4)$ & $33(86.8)$ & 0.202 \\
\hline $\begin{array}{l}\text { 10. Choosing a syringe and needle compatible with the volume to be administered is } \\
\text { safer, reducing the risk of error }\end{array}$ & $36(94.7)$ & $37(97.4)$ & $35(92.1)$ & 0.368 \\
\hline 11. Checking the IV medication label with prescription & $38(100)$ & $38(100)$ & $36(94.7)$ & 0.135 \\
\hline $\begin{array}{l}\text { 12. Observing the absence of particles, color change, cracks and/or leaks in the } \\
\text { medicine ampoule }\end{array}$ & $38(100)$ & $38(100)$ & $36(94.7)$ & 0.135 \\
\hline 13. Observing expiration date of IV medication & $37(97.4)$ & $37(97.4)$ & $37(97.4)$ & 1.000 \\
\hline 14. Explaining the procedure for administering IV medication to patient/companion & $34(89.5)$ & $36(94.7)$ & $34(89.5)$ & 0.513 \\
\hline 15. Monitoring and recording, checking medications with prescription & $36(94.7)$ & $35(92.1)$ & $33(86.8)$ & 0.311 \\
\hline 16. Checking patient name by asking them and/or their companion & $15(39.5)$ & $25(65.8)$ & $36(94.7)$ & $<0.0001$ \\
\hline 17. Installing medication according to medical prescription & $35(92.1)$ & $34(89.5)$ & $36(94.7)$ & 0.651 \\
\hline $\begin{array}{l}\text { 18. Recording/checking the medical record/prescription immediately after administering IV } \\
\text { medication }\end{array}$ & $35(92.1)$ & $38(100)$ & $37(97.4)$ & 0.174 \\
\hline 19. Properly disposing of used material after administering IV medication & $34(89.5)$ & $36(94.7)$ & $38(100)$ & 0.050 \\
\hline
\end{tabular}

* Pre-test: before training; ${ }^{+}$Post-test 1 : immediately after training; ${ }^{\text {}}$ Post-test 2 : six months after training; ${ }^{\circledR}$ Friedman test; IV: intravenous. 
Table 2 - Distribution of the number of professionals according to reaction evaluation after training - Fortaleza, CE, 2018-2019.

\begin{tabular}{|c|c|c|c|}
\hline Reaction evaluation items & $\begin{array}{c}\text { Inadequate* } \\
N(\%)\end{array}$ & $\begin{array}{c}\text { Adequate }^{+} \\
\text {N }(\%)\end{array}$ & $\mathbf{p}^{\ddagger}$ \\
\hline 1. Training evaluation & $7(18.4)$ & $31(81.6)$ & $<0.0001$ \\
\hline 2. Training goals & $7(18.4)$ & $31(81.6)$ & $<0.0001$ \\
\hline 3. Training reached established goals & $6(15.8)$ & $32(84.2)$ & $<0.0001$ \\
\hline 4. Training subject relevant to professional practice & $2(5.3)$ & $36(94.7)$ & $<0.0001$ \\
\hline 5. Interestingly presented subject & $4(10.5)$ & $34(89.5)$ & $<0.0001$ \\
\hline 6. Facilitator was an effective communicator & $2(5.3)$ & $36(94.7)$ & $<0.0001$ \\
\hline 7. Facilitator was well prepared & $3(7.9)$ & $35(92.1)$ & $<0.0001$ \\
\hline 8. Resources used during training were effective for learning & $8(21.0)$ & $30(79.0)$ & $<0.0001$ \\
\hline 9. Materials delivered will be useful to me & $13(34.2)$ & $25(65.8)$ & 0.073 \\
\hline 10. I will be able to apply the subject covered in training in my professional practice & $1(2.6)$ & $37(97.4)$ & $<0.0001$ \\
\hline 11. There was a good balance between content and time used for training & $16(42.1)$ & $22(57.9)$ & 0.418 \\
\hline 12. Training will help carrying the work more efficiently & $2(5.3)$ & $36(94.8)$ & $<0.0001$ \\
\hline
\end{tabular}

*Inadequate: answers 1 (poor), 2 (reasonable) and 3 (good); ${ }^{+}$Adequate: answers 4 (very good) and 5 (excellent); ${ }^{*}$ Binomial test.

six months, with a statistically significant difference in the following actions: removing ornaments to sanitize hands $(\mathrm{p}=0.029)$; obligatorily using gloves to administer IV medication ( $\mathrm{p}=0.022)$; administering IV medication using gloves, mask and goggles $(p=0.009)$; and checking patient name by asking them and/or their companion ( $p<0.0001)$. Although no statistical difference was identified in the other actions, there was an increase in the percentage of hits before and after training in most questions, which remained above $80 \%$. Table 2 shows the results of the evaluation of participants' reaction in relation to the training.

In the evaluation of participants' reaction, carried out immediately after the end, it was found that, of the 12 items, 10 presented a statistically significant difference $(p<0.0001)$, as most nursing professionals considered the training to be very good or excellent. Although the items "The materials delivered will be useful to me" and "There was a good balance between content and time used for training" did not show a significant difference, there was a predominance of professionals who reported positive reactions, with a percentage of $65.8 \%$ and $57,9 \%$, respectively.

\section{DISCUSSION}

The profile of the evaluated sample, in relation to sociodemographic and professional characteristics, is similar to that reported in other studies ${ }^{(9-10)}$. These characteristics are important, as employers value people with a profile to take positions in the work environment who are able to expand skills, discover how to achieve results, seek to update knowledge, know how to determine priorities and prepare for changes ${ }^{(11)}$.

For learning evaluation, it was noticed that participants had previous knowledge about medication administration and patient safety. It is important to emphasize that the institution in which the research was carried out is a teaching hospital that maintains a permanent education nurse in the pediatrics sectors. However, some participants prepared and administered medications without having prior knowledge of the systematization described in the Ministry of Health's Safety Protocol in Prescription, Use and Administration of Medicines (Protocolo de Segurança na Prescrição, Uso e Administração de Medicamentos), or were unaware that the medication system is composed of processes of prescription, dispensing and administration ${ }^{(6)}$. These knowledge gaps can weaken care and compromise patient safety in activities related to the preparation and administration of IV medications.

The item related to the understanding of professionals about medical prescription had a percentage of hits above $80 \%$. Prescription is an important written communication tool among healthcare professionals and can provide safe administration $^{(12)}$. In the evaluation of the item reading medical prescription, referring to checking patient name by asking their companion, there was a significant improvement in the scores from the pre- to the post-test.

Checking inpatient name (right patient) is an important action and is part of the "nine rights" of medication administration $^{(6)}$, namely: right patient; right medication; right way; right time; right dose; right documentation (right record from the administration); correct orientation; right form; hits. Therefore, the use of an identification bracelet is an indispensable strategy to identify patients who are cared for by several professionals and in different shifts ${ }^{(13)}$. The lack of its use expresses overconfidence on the part of professionals and can contribute to the occurrence of errors ${ }^{(14-15)}$.

Items with content on hand hygiene and use of Personal Protective Equipment (PPE) had an adequate level of correctness, with a significant difference between the pre- and post-tests. A survey that evaluated 3,402 actions related to the nursing team's care practice during medication administration through a central vascular catheter observed that, among those with negative indices, those related to hand hygiene (1.3\%) and ampoule and vial disinfection (1.6\%) stood out ${ }^{(16)}$. 
The actions taken by the nursing staff in the administration of medication are complex, since this is the last barrier of the medication system capable of preventing damage associated with it. This activity is developed in partnership with other areas, as it is part of the final phase of the medication system $^{(5)}$.

A research ${ }^{(17)}$ carried out with 40 undergraduate nursing students on realistic simulation to approach the administration of medication via the parenteral route identified a significant improvement $(p=0.001)$ in knowledge about the technique of parenteral medication administration between pre- and post-tests after using realistic simulation. Overall, the level of self-confidence improved after realistic simulation in the different phases of the study $(p=0.03)$.

In the action of proper dispensing of the material used after administering IV medication, an adequate level of knowledge was found six months after training (100\%). A study carried out in an Intensive Care Unit based on direct observation of the nursing team's care practice identified that the proper disposal of sharps (97\%) was the action with the best positivity rate ${ }^{(16)}$. It is important to say that the solid waste generation speed is higher than the environment is capable of absorbing and this has environmental, social and public health impacts ${ }^{(18)}$.

In the current scenario, there is a constant need to seek knowledge, with an educational purpose. For this purpose, different learning models are developed that change in different contexts of action ${ }^{(19)}$. Thus, for a training to have a positive effect and reach the expected impact, it is important to encourage participants' knowledge through discussions. The, it can be said that the impact of knowledge in the work environment is the reason for the existence of educational actions. The systematic acquisition of knowledge is not enough, it is necessary for them to be able to generate change in professionals' work and in the outcomes of institutions.

The practice of evaluations, in addition to satisfaction and learning, means an important advance in the technique of evaluating educational actions ${ }^{(20)}$. Therefore, to put into practice permanent education actions, such as training, it is necessary to use dynamic technological resources that incorporate better adaptation and provide learning, due to the fact that healthcare professionals' education is closely related to the quality of care provided ${ }^{(21)}$.

The results of a research ${ }^{(22)}$ pointed to the need for knowledge about contents related to medication administration. In another study ${ }^{(23)}$, which evaluated the effects of an educational intervention program on improving pediatric nurses' skills, the results demonstrated significant improvements in healthcare practice for adolescents after participating in a three-week structured training program.

The level of knowledge of nurses about ventrogluteal intramuscular administration and the effects of a given training were evaluated by a study ${ }^{(24)}$. The data obtained showed positive impacts on participants' knowledge and practice, above all greater awareness and a higher level of knowledge.

The impact of training can be evaluated by transparency of learning and influence of the institutional process on trainees' work when the correct application of skills is $\operatorname{made}^{(7)}$. In this way, it is essential to evaluate professionals' knowledge, as well as their work, to identify gaps in knowledge, skills and attitudes, promoting the construction and implementation of strategies for their development ${ }^{(21-25)}$.

When evaluating the study participants' reactions, it was found that, among the 12 items evaluated in the training program, ten were considered very good or excellent. Similar data was identified in another study that also achieved satisfactory results in reaction evaluation ${ }^{(25)}$. This type of evaluation becomes important, because the training influences participants' perception and has an impact on work practice ${ }^{(7)}$. Based on the results obtained, it is observed that the present study had a positive effect on nursing practice, teaching and research. Moreover, nursing staff awareness on the subject was noticed and that the teaching method used could be a model for future research.

It is of fundamental importance that managers and training centers evaluates professionals' work based on skills to contribute to identifying professionals' knowledge gaps, skills and attitudes, thus promoting the construction and implementation of strategies for their development ${ }^{(26)}$. Thus, for this training to achieve a positive effect and the expected impact, it was important to encourage participants' knowledge through discussions.

Thus, it is considered that training was effective, as it resulted in: positive learning by improving participants' knowledge; judgment of proper behavior; improvement in actions related to the IV medication administration process; and evaluation of nursing team's positive reaction. In theory, the IV medication administration process training program presented positive effects on nursing professionals' reaction, learning, behavior and care practice, resulting in positive results regarding incident prevention and pediatric cardiac patient safety promotion related to medication administration.

It is considered as a limiting factor that the study was carried out with nursing professionals from specific sectors in a single institution and the small sample size, which may be considered a limitation of methodological quality. Furthermore, only two of the four levels of training evaluation (reaction and learning) were carried out, and the investigation at four levels would be more substantial ${ }^{(7)}$.

\section{CONCLUSION}

For learning evaluation, there was evidence of an increase in the number of hits for questions related to learning after training, with a progressive evolution, considering that the hits presented a hit rate $>80 \%$, and learning evaluation was adequate. Some questions showed a statistically significant difference $(p<0.05)$. For evaluation of nursing team professionals' reaction in relation to training, a positive participants' reaction was noticed, mainly in relation to content on pediatric patient safety, being considered very relevant by participants. Thus, the training had positive effects on participants' learning and reaction, contributing to patient safety in medication administration in the context of pediatric cardiology. 
Dissemination of knowledge about patient safety and incident prevention in the workplace is recommended, in order to foster discussions, exchange of experiences and improvements in practice. Surveys using behavior and outcome evaluations are important to evaluate training consistency.

\section{RESUMO}

Objetivo: Avaliar o efeito de um treinamento sobre administração de medicamento endovenoso em pacientes pediátricos na aprendizagem e reação da equipe de enfermagem. Método: Estudo quase experimental (pré- e pós-teste), com 38 profissionais da enfermagem que participaram de um treinamento sobre administração de medicamento endovenoso (EV) em pacientes pediátricos cardiopatas. Para coleta de dados, aplicou-se um questionário com 19 itens para avaliar a aprendizagem dos participantes antes (préteste) e após (pós-teste) o treinamento. Analisaram-se os dados por estatística descritiva e analítica (testes binomial e Friedman). Resultados: Predominaram enfermeiras (52,6\%), média de 41,2 anos de idade e 9,8 anos de experiência profissional na pediatria. Na avaliação da aprendizagem, houve aumento no índice de acertos do pré-teste para o pós-teste em 13 itens, com diferença significativa $(\mathrm{p}<0,05)$ nos quesitos: retirar adornos para higienizar as mãos; usar luva ao administrar medicamento; administrar medicamento com luva, máscara e óculos de proteção; e conferir nome do paciente perguntando a ele ou ao acompanhante. Conclusão: O treinamento apresentou efeitos positivos na aprendizagem e reação dos profissionais de enfermagem.

\section{DESCRITORES}

Segurança do Paciente; Infusões Intravenosas; Erros de Medicação; Enfermagem Pediátrica; Capacitação em Serviço.

\section{RESUMEN}

Objetivo: Evaluar el efecto del entrenamiento sobre la administración de fármacos intravenosos en pacientes pediátricos sobre el aprendizaje y la reacción del equipo de enfermería. Método: Estudio cuasiexperimental (pre- y post-test), con 38 profesionales de enfermería que participaron en la formación sobre la administración de medicación intravenosa (IV) en pacientes pediátricos con cardiopatías. Para la recolección de datos, se aplicó un cuestionario con 19 ítems para evaluar el aprendizaje de los participantes antes (pre-test) y después (post-test) del entrenamiento. Los datos fueron analizados mediante estadística descriptiva y analítica (pruebas binomial y Friedman). Resultados: Hubo predominio de enfermeras (52,6\%), edad media 41,2 años y 9,8 años de experiencia profesional en pediatría. En la evaluación de aprendizajes, hubo un aumento en la tasa de aciertos del pre-test al post-test en 13 ítems, con una diferencia significativa ( $\mathrm{p}<0.05)$ en los ítems: quitar los adornos para desinfectar las manos; usar guantes al administrar medicamentos; administrar medicamentos con guantes, mascarilla y anteojos; y comprobar el nombre del paciente preguntándole a su acompañante. Conclusión: La formación tuvo efectos positivos en el aprendizaje y la reacción de los profesionales de enfermería.

\section{DESCRIPTORES}

Seguridad del Paciente; Infusiones Intravenosas; Errores de Medicación; Enfermería Pediátrica; Capacitación en Servicio.

\section{REFERENCES}

1. Silva JSD, Almeida PHRF, Perini E, Pádua CAM, Rosa MB, Lemos GS. Prescription and administration errors involving a potentially dangerous medicine. Rev Enferm UFPE on line. 2017;11(10):3707-17. DOI: https://doi.org/10.5205/reuol.12834-30982-1-SM.1110201702

2. Vória JO, Padula BLD, Abreu MNS, Correa AR, Rocha PK, Manzo BF. Compliance to safety barriers in the medication administration process in pediatrics. Texto Contexto Enferm. 2020;29:e20180358. DOI: https://doi.org/10.1590/1980-265x-tce-2018-0358

3. Hfaiedh N, Kabiche S, Delescluse C, Balde I-B, Merlin S, Carret S, et al. Performing a preliminary hazard analysis applied to administration of injectable drugs to infants. J Eval Clin Pract. 2017;23(4):875-81. DOI: https://doi.org/10.1111/jep.12748

4. Instituto para Práticas Seguras no Uso de Medicamentos. Uso seguro de medicamentos em pacientes pediátricos. Boletim ISMP Brasil. 2017;6(4):1-7 [cited 2021 Jun 10]. Available from: http://www.ismp-brasil.org/site/wp-content/uploads/2017/12/BOLETIM-ISMPBRASILPEDIATRIA.pdf

5. World Health Organization. Medication Without Harm - Global Patient Safety Challenge on Medication Safety [Internet]. Geneva: World Health Organization, 2017. [cited 2021 Apr 10]. Available from: http://www.ismp-brasil.org/site/wp-content/uploads/2017/05/WHOBrochure-GPSCMedication-Without-Harm-1.pdf

6. Brasil. Ministério da Saúde. Protocolo de Segurança na Prescrição, Uso e Administração de Medicamentos [Internet]. Brasília: Ministério da Saúde; 2013 [cited 2021 Apr 04]. Available from: https://www20.anvisa.gov.br/segurancadopaciente/index.php/publicacoes/item/ seguranca-na-prescricao-uso-e-administracao-de-medicamentos

7. Kirkpatrick DL, Kirkpatrick JD. Como avaliar programas de treinamento de equipes: os quatro níveis. Rio de Janeiro: SENAC-RIO; 2010.

8. Pasqual L. Piscometria: teoria dos testes na psicologia e na educação. 4th ed. Petrópolis: Vozes, 2011.

9. Llapa-Rodriguez EO, Silva LSL, Menezes MO, Oliveira JKA, Currie LM. Safe patient care in the preparation and administration of medicines. Rev Gaúcha Enferm. 2017;38(4):e2017-00291-46. DOI: http://dx.doi.org/10.1590/1983-1447.2017.04.2017-0029

10. Mangilli DC, Assunção MT, Zanini MTB, Dagostin VS, Soratto MT. Atuação ética do enfermeiro frente aos erros de medicação. Enferm Foco [internet]. 2017 [cited 2021 Apr 04];8(1):62-6. Available from: http://revista.cofen.gov.br/index.php/enfermagem/article/view/878/360

11. Manenti SA, Ciampone MHT, Mira VL, Minami LF, Soares JMS. The construction process of managerial profile competencies for nurse coordinators in the hospital field. Rev Esc Enferm USP. 2012;46(3):727-33. DOI: https://doi.org/10.1590/S0080-62342012000300027

12. Jacobsen TF, Mussi MM, Silveira MPT. Analysis of prescription errors in a hospital of southern Brazil. Rev Bras Farm Hosp Serv Saúde [Internet]. 2015 [cited 2021 Apr 04];6(3):23-6. Available from: https://www.rbfhss.org.br/sbrafh/article/view/23

13. Oliveira JLC, Cervilheri AH, Haddad MCL, Magalhães AMM, Ribeiro MRR, Matsuda LM. Interface between accreditation and patient safety: nursing team perspectives. Rev Esc Enferm USP. 2020;54:e03604. DOI: https://doi.org/10.1590/S1980-220X2018053703604 
14. Peres MA, Wegner W, Kantorski KJC, Gerhardt LM, Magalhães AMM. Perception of family members and caregivers regarding patient safety in pediatric inpatient units. Rev Gaúcha Enferm. 2018;39:e2017-0195. DOI: https://doi.org/10.1590/1983-1447.2018.2017-0195

15. Hoffmeister LV, Moura GMSS. Use of identification wristbands among patients receiving inpatient treatment in a teaching hospital. Rev Latino-Am Enfermagem. 2015;23(1):36-43. DOI: http://dx.doi.org/10.1590/0104-1169.0144.2522

16. Oliveira JKA, Llapa-Rodriguez EO, Lobo IMF, Silva LSL, Godoy S, Silva GG. Patient safety in nursing care during medication administration. Rev Latino-Am Enfermagem. 2018;26:3017. DOI: https://doi.org/10.1590/1518-8345.2350.3017

17. Nascimento MS, Magro MCS. Realistic simulation: method of improving knowledge and self-confidence of nursing students in the administration of medication. Rev Min Enferm [Internet]. 2018 [cited 2021 Apr 04];22:e-1094. DOI: http://www.reme.org.br/artigo/ detalhes/1232

18. Guerrieri FM, Henkes JÁ. Análise do descarte de medicamentos vencidos: um estudo de caso no município de Rio das Ostras (RJ). Revista Gestão e Sustentabilidade Ambiental. 2017;6(1):566-608. DOI: http://dx.doi.org/10.19177/rgsa.v6e12017566-608

19. Tavares APC, Leite BS, Silveira IA, Santos TD, Brito WAP, Camacho ACLF. Analysis of Brazilian publications on distance education in nursing: integrative review. Rev Bras Enferm. 2018;71(1):214-22. DOI: http://dx.doi.org/10.1590/0034-7167-2016-0454

20. Ferreira PS, Mendonça FTNF, Souza DJ, Paschoal VD, Lipp UG, Santos AS. Avaliação do suporte à transferência e do impacto da educação permanente na atenção primária à saúde. REFACS. 2017;5(3):404-14. DOI: https://doi.org/10.18554/refacs.v5i3.2406

21. Mikako Y, Yuka M, Koichi Y, Naoko S, Masaru M, Masako Y, et al. Efficacy of an education program for nurses that concerns the use of pointof-care ultrasound to monitor for aspiration and pharyngeal post-swallow residue: A prospective, descriptive study. Nurse Educ Pract. 2020;44(2020):102749. DOI: https://doi.org/10.1016/j.nepr.2020.102749

22. Praxedes MFS, Telles-Filho PCP, Miasso AI, Pereira-Júnior AC. Medicines administration: identification and analysis of the educational needs of nurses. Rev Enferm UFPE on line. 2015;9(1):76-83. DOI: https://doi.org/10.5205/1981-8963-v9i1a10309p76-83-2015

23. Lee RLT, Wang JJ. Effectiveness of an adolescent healthcare training programme for enhancing paediatric nurses' competencies. J Clin Nurs. 2016;25(3):300-10. DOI: https://doi.org/10.1111/jocn.13395

24. Gülnar E, Özveren $\mathrm{H}$. An evaluation of the effectiveness of a planned training program for nurses on administering intramuscular injections into the ventrogluteal site. Nurse Educ Today. 2016;36(3):360-3. DOI: https://doi.org/10.1016/j.nedt.2015.09.001

25. Ferreira AMV, Sabino LMM, Nascimento LA, Penha JC, Barbosa LP, Lima FET, et al. Analysis of the reaction and behavior of nurses after training on young child feeding. Rev Bras Enferm. 2019;72(Suppl.1):206-12. DOI: http://dx.doi.org/10.1590/0034-7167-2017-0529

26. Soares MI, Leal LA, Resck ZMR, Terra FS, Chaves LDP, Henriques SH. Avaliação de desempenho por competências em enfermeiros hospitalares. Rev. Latino-Am. Enfermagem [Internet]. 2019 [citado 2020 Jan 18];27:e3184. Disponível em: http://www.scielo.br/scielo. php?script=sci_arttext\&pid=S0104-11692019000100373\&lng=pt. Epub 14-Out-2019. http://dx.doi.org/10.1590/1518-8345.3173.3184. 